\title{
AN OVERVIEW OF FISCAL CONSOLIDATION PROCESS IN THE EUROPEAN UNION
}

\author{
Iulia Andreea Bucur \\ "Vasile Alecsandri" University of Bacău \\ iuliaandreea.bucur@gmail.com \\ Mircea Muntean \\ "Vasile Alecsandri” University of Bacău \\ mircea.muntean@ub.ro
}

\begin{abstract}
This paper aims to explore, based on theoretical and empirical research in the field and on data available on Eurostat and European Commission, in the context of financial significant imbalances and thus of the financial stress in the EU countries and especially in the Euro area, the main developments in the fiscal consolidation process given the fiscal effort of each country towards fiscal union. Since the financial crisis started in 2008, many EU Member States demonstrates an obvious macroeconomic imbalance which requires increased responsibility regarding fiscal developments. The impact of the crisis and the causes of sovereign debt high levels trends varied between EU countries as well as the budget deficit levels. Thus, the main priority for EU members must be the continuation of differentiated fiscal consolidation, given the specificities of each economy, favoring growth. The medium-term fiscal policy needs to focus on consolidating public finances along with restoring long-term sustainability.
\end{abstract}

\section{Keywords}

EU fiscal consolidation; financial stress; sovereign debt crisis; public deficit; fiscal effort

\section{JEL Classification}

E62; F36; G01; H62; H63

\section{Introduction}

Along with completing the customs union as a first step towards European economic integration, followed by a milestone represented by the creation of the common market, essential for economic growth and convergence, the latest major step of the process of European unification, namely the adoption of the single currency in the European Monetary Union (EMU) in 1999 (Sapir, 2011) is unlikely to be the final step (Bargain et al, 2012).

The economic crisis that started in 2008 and led to the deterioration of worldwide and also European Union (EU) public finances represents a huge challenge not only for EU member states, but for the entire European assembly. In this context, the European economic integration takes a number of additional meanings, reason that confirms once again that the importance of the aspects of its manifestation does not diminish over time, but rather increases (Bucur, 2013). Furthermore, the widespread view of the process and thus of the future of the Euro area (EA) consists of two options: either it is complemented by a fiscal union, or it will fall apart. The creation of fiscal union is interpreted, on the one hand, as an introduction of a set of balanced budget rules, and, on the other hand, as a more ambitious project of creating a federal government with significant tax and spending powers comparable to other like US federation (Bordo et al, 2011). Trying to find the answer to the question whether the Euro area needs to move towards a fiscal union or it might work under a different 
institutional arrangement, there have been identified five possible elements of a fiscal union such as: (i) fiscal rules for the member states, policy coordination and supervision, (ii) a crisis resolution mechanism, (iii) a joint guarantee for government debt, (v) a fiscal equalization and other mechanisms for transfers between countries and (iv) a larger EU budget and European taxes (Fuest \& Peichl, 2012).

Macroeconomic stability and balanced and sustainable economic growth in the EU requires as a prerequisite the existence of solid and sustainable public finances as the single monetary policy can not react to the specific situation for each country and the repercussions due to their unsustainable fiscal policies are more powerful, as clearly the recent financial crisis demonstrated (Bucur \& Dragomirescu, 2013) due to banking crisis, loss of competitiveness in the foreign trade and deficiencies in controlling public expenditures and revenues (Viren, 2012).

In our study, based on theoretical and empirical research in the field and on data available on Eurostat and European Commission, we intend to capture, in the context of financial significant imbalances and thus of the financial stress in the EU countries and especially in the Euro area, the main developments in the fiscal consolidation process given the fiscal effort of each country in supporting the consolidation towards fiscal union.

The impact of the financial crisis and the causes of sovereign debt crisis trends varied between European countries. Yet, overall, the continuously increasing of public debt in some EU member states and its heterogeneity reflects the cumulative effect of high primary deficits, of negative or weak economic growth and also of high interest expenditures. The gradual accumulation of substantial budget deficits most of all since the financial crisis started in 2008, which also led to the increased sovereign debt in many EU Member States demonstrates an obvious macroeconomic imbalance and also requires increased responsibility regarding fiscal developments. In this context, the main priority for EU members must be the continuation of differentiated fiscal consolidation, given the specificities of each economy, favoring growth. Thus medium-term fiscal policy needs to focus on consolidating public finances along with restoring long-term sustainability.

The paper is structured as follows. In the second section we briefly pointed out some of the main causes of EU sovereign debt crisis and in some EU states which are also EA members. Given the fiscal sustainability of the EU Member States and particularly of those of the Euro area, an overview of the financial stress in the EU is also presented in this section. The third section contains the main developments in budget deficits and public debt to GDP across EU member states and the impact of austerity fiscal measures in some Euro area states, followed in fourth section by the recent adjustments in fiscal consolidation effort of the members, given the role of budgetary institutions in improving fiscal performance at the essential stages of fiscal policy-making process. The last section contains a brief summary of our study and the concluded remarks.

\section{Sovereign debt crisis and the financial stress in the EU}

The sustainability of sovereign debt is not a new issue in the Euro area, various researches in the field focus on it even before the onset of financial imbalances.

Once the financial crisis hit, countries such as Ireland and Portugal have failed to show adequate control of public finances, their level showing an alarming increase reaching up to $123.3 \%$ in Ireland in 2013 and up to $128.0 \%$ in Portugal in the same year. Under the impact of the financial crisis, government debt to GDP increased in Belgium, France, Spain, UK and Germany, reaching in 2013 values higher than the limit set, of 104.5\%, 92.2\%, 92.1\%, 87.2\% and 76.9\%. 
With of poor management of government debt, Greece appears as the state with the highest level, reaching in 2013 the value of $174.9 \%$ of GDP. Like Greece, Italy has also a high degree of fiscal indiscipline, even before the financial turmoil period, the public debt value reaching up to $127.9 \%$ of GDP in 2013, situation that is in opposition to that of the fiscal balance $(-2.8 \%$ of GDP in the same year), which can not be said in case of Greece.
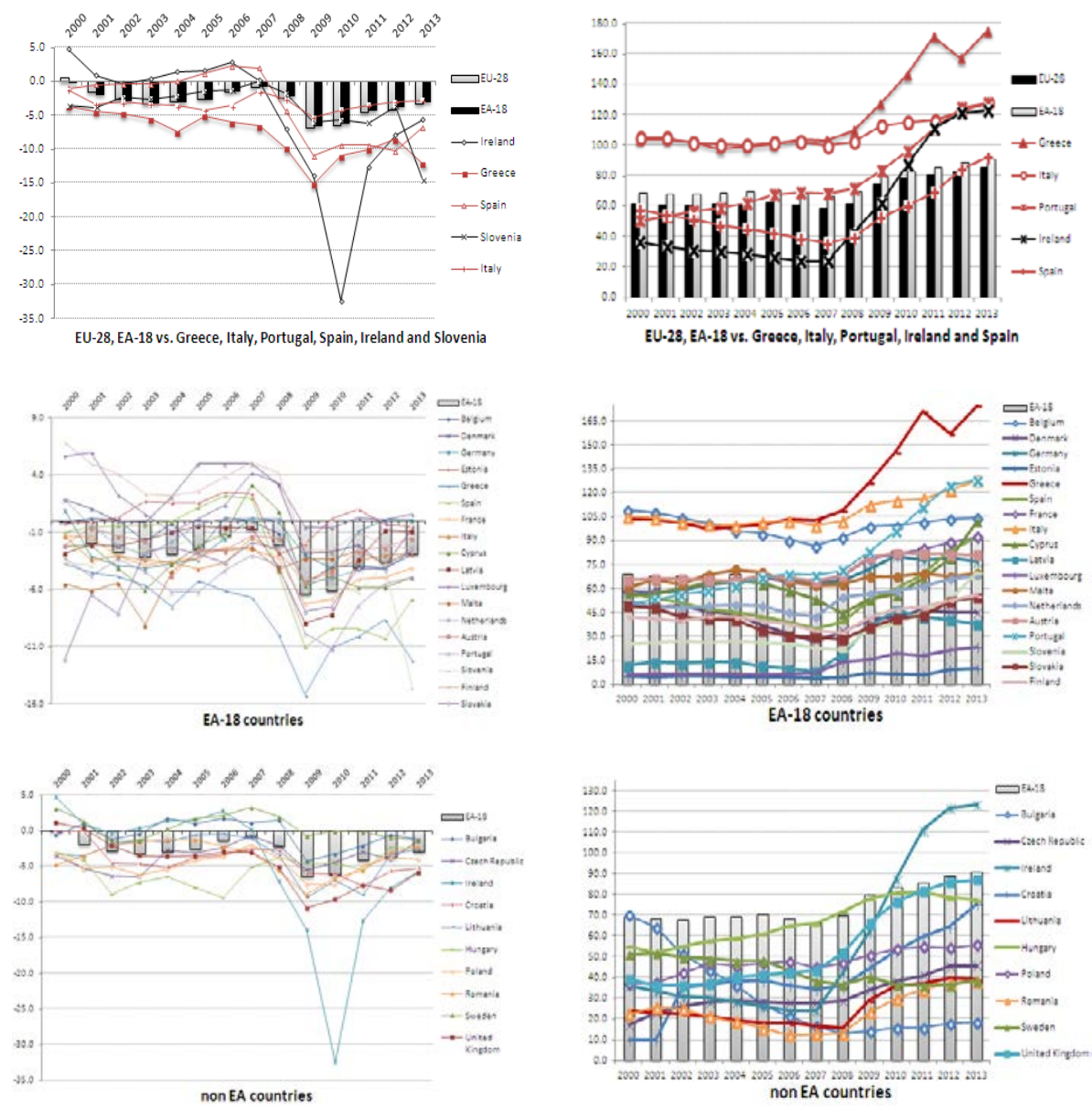

Figure 1 Public deficit trends in European Union, 2000-2013 (\% of GDP)

Source: Own processing, based on the data available on Eurostat

Figure 2 Government consolidated gross debt trends in European Union, 2000-2013 (\% of GDP)

Source: Own processing, based on the data available on Eurostat

The gradual accumulation of substantial budget deficits (Figure 1), most of all since the financial crisis started in 2008, which also led to an increased sovereign debt in many EU states (Figure 2), especially in Greece, Ireland, Portugal, Italy or Spain demonstrates an obvious macroeconomic imbalance and also requires increased responsibility regarding fiscal developments in the EU Member States. Thus mediumterm fiscal policy needs to focus on consolidating public finances along with restoring long-term sustainability (Olden et al, 2012).

While in Spain and Ireland the origin of sovereign debt crisis lies mainly in the private sector, in the real estate sector and was passed onto the public sector through 
bank bailouts (Semmler \& Semmler, 2013), in other countries such as Greece, Portugal or Italy is due to the government sector with chronic macroeconomic imbalances (Stein, 2011) (Table 1). The sovereign debt in the latter mentioned countries was high in earlier times, partly since the '80s and started to rise more and more since the crisis started.

Table 1 Causes of debt crisis trends in Greece, Portugal, Ireland and Spain

\begin{tabular}{lrrrr}
\hline & $\begin{array}{r}\text { Government } \\
\text { Structural Balances } \\
\text { (\% of GDP) }\end{array}$ & $\begin{array}{r}\text { Government } \\
\text { Net Debt } \\
\text { (\% of GDP) }\end{array}$ & $\begin{array}{r}\text { Interest } \\
\text { Payments } \\
\text { (\% of GDP) }\end{array}$ & $\begin{array}{r}\text { Capital Gains } \\
\text { (annual evolution } \\
\text { of Real Estate Prices) } \\
\text { Mean, 1996-2007 }\end{array}$ \\
\hline Greece & -4.76 & 80.25 & 1.16 & 10.10 \\
\hline Portugal & -4.50 & 50.08 & 1.42 & 3.30 \\
\hline Ireland & -2.24 & 27.30 & 0.43 & 13.30 \\
\hline Spain & -1.28 & 42.53 & 0.53 & 9.71 \\
\hline
\end{tabular}

Source: Apud. Stein, J. L. (2011), The Diversity of Debt Crisis in Europe, CESIFO Working Paper, No.

3348, based on EconStats, IMF World Economic Outlook, and BIS Housing Statistics, IFC Bulletin, No.31

If until 2007 it has been confirmed that debt in the EU is sustainable (Semmler et al, 2005), since the beginning of the crisis, fiscal sustainability in the EU and especially of the Euro area is clearly under stress. It is widely accepted that financial stress is a negative state and also a multidimensional problem. However it is the subject of diverse definitions and interpretations (Kliesen et al, 2012). A monitor for financial instability that indicates the interaction of financial vulnerabilities and the size of exogenous shocks (Grimaldi, 2010; Grimaldi, 2011) is the level of Financial Stability Index (FSI).
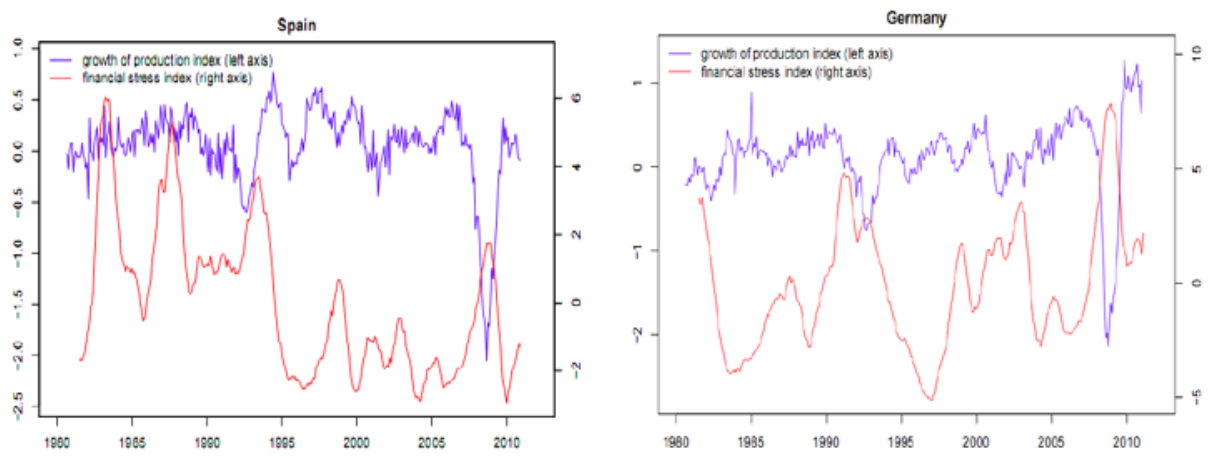

Figure 3 FSI and IPI for Spain and Germany, 1980-2011

Source: Semmler, W., Semmler, A. (2013), The Macroeconomics of the Fiscal Consolidation in the European Union, SSRN Working paper

Using the IMF (2011) FSI, available for most of the EU states, which indicates the financial stress, in contrast with the OECD (2011) Industrial Production Index (IPI), Semmler \& Semmler (2013) provided some details regarding the relationship between financial stress regimes and economic activity. An analysis for two of EU member states, Spain and Germany (Figure 3), highlighted a significant inverse correlation between indicators, summarized as follows: "stress is low in expansions and high in a regime of contraction” (Mittnik \& Semmler, 2012; Semmler \& Semmler, 2013). 


\section{Developments in fiscal consolidation process}

As we mentioned in the previous section, the impact of the financial crisis and the causes of sovereign debt crisis trends varied between European countries. Thus, it is obvious that fiscal integration in the EU faces major challenges arising from the need to reduce the level of indebtedness in the context of bleak economic growth prospects, of the pressure on long-term expenditures and of fiscal burden which is quite high (Bucur \& Dragomirescu, 2013) and an effective management of intergovernmental fiscal reforms is essential (Kim \& Vammalle, 2012).

Despite various determinants of debt crisis, an austerity policy which establishes a permanent constraint on fiscal policy was enacted and imposed. The adoption of the Six Pack, entered into force in 2011, the monitoring of fiscal policies of the EA states, the implementation in 2012 of specific surveillance procedures for the countries facing financial stability risks and also the introduction of a fiscal discipline represent important steps in reforming the economic and budgetary surveillance in EU.

\section{Developments in budget deficits}

In the context of intensifying market tensions and of increasing the budget balance among EU countries from $0.9 \%$ of GDP in EU in 2007 up to $6.9 \%$ of GDP in EU in 2009 and EA countries from $0.7 \%$ of GDP up to $6.4 \%$ of GDP during the same period, since 2009 the budget balance recorded a slight improvement which indicates visible efforts in reduction deficits at least at the EU and EA headline level (Table 2).

Table 2 Budget deficit in EU-28 and EA-18, 2000-2013 (\% of GDP)

\begin{tabular}{|c|c|c|c|c|c|c|c|c|c|c|c|c|c|c|}
\hline & 2000 & 2001 & 2002 & 2003 & 2004 & 2005 & 2006 & 2007 & 2008 & 2009 & 2010 & 2011 & 2012 & 2013 \\
\hline EU-28 & 0.6 & -1.5 & -2.6 & -3.2 & -2.9 & -2.5 & -1.5 & -0.9 & -2.4 & -6.9 & -6.4 & -4.5 & -4.2 & -3.2 \\
\hline EA-18 & -0.1 & -1.9 & -2.7 & -3.1 & -2.9 & -2.5 & -1.3 & -0.7 & -2.1 & -6.4 & -6.1 & -4.1 & -3.6 & -2.9 \\
\hline
\end{tabular}

Further improvement is expected in fiscal consolidation, albeit at a slower pace, although in the next few years some countries will be facing sizeable levels of public deficit (European Commission, 2013).

An overview on the trends and improvements on the public deficit at the EA countries (Figure 4) indicates significant efforts in fiscal consolidation for: Latvia, with a reduction in the fiscal deficit of $8 \%$ of GDP, Slovakia, Portugal and Spain whose deficit reduction exceeded 4\% of GDP, Austria, Netherlands, France, Germany and even Greece whose deficit reduction exceeded 3\% of GDP.
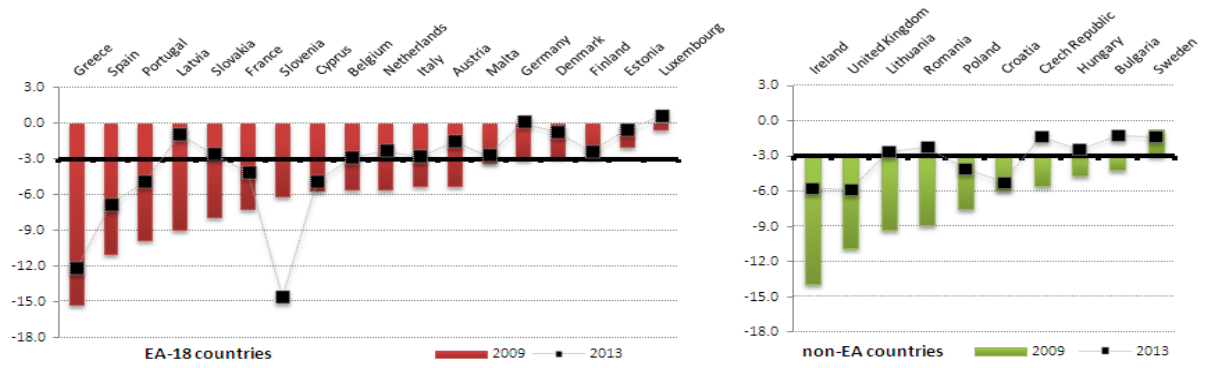

Figure 4 Trends and improvements in public deficit for EA-18 and non-EA member states, 2013/2009 (\% of GDP)

Source: Own processing, based on the data available on Eurostat 
Noteworthy, the budget balance for EA member Slovenia has strongly worsened since 2009, especially during 2012-2013 when the deficit increased with $10.9 \%$ of GDP, reaching the highest level of the EA states of $-14.6 \%$ of GDP.

Regarding the non-EA member states, we observe (Figure 4) significant efforts in fiscal consolidation for: Ireland, with a reduction in the fiscal deficit of $8.2 \%$ of GDP, even though its level of $-5.7 \%$ of GDP in 2013 exceeded the imposed limit. Lithuania and Romania also have reduced their deficit with over 6\% of GDP, reaching in 2013 a level below the required. United Kingdom recovered since 2009 5\% of GDP, although its deficit level in 2013 is of 5.8\% of GDP, quite similar situation to that of Poland which, despite its efforts, recorded a level of deficit of 4\% of GDP in 2013. Other countries such as Bulgaria and Hungary face a better situation, given that their deficit level of $1.2 \%$ of GDP and respective of $2.4 \%$ of GDP in 2013 is below the Maastricht requirement. Only Sweden, with a deficit level within the limit of $3 \%$ of GDP, recorded a slight increase from $0.7 \%$ of GDP in 2009 to 1.3\% of GDP in 2013.

\section{Developments in public debt}

Regarding the government debt among European countries, the upward trend of its average value, especially since 2009, is obvious. In 2013, the EU headline debt came in at $85.4 \%$ of GDP from $74.5 \%$ of GDP in 2009 while that of the Euro area came in at $90.9 \%$ of GDP from $74.5 \%$ of GDP in 2009 (Table 3) and they are projected to rise in the next period (European Commission, 2013).

Table 3 Public debt in EU-28 and EA-18, 2000-2013 (\% of GDP)

\begin{tabular}{lllllllllllllll}
\hline & $\mathbf{2 0 0 0}$ & $\mathbf{2 0 0 1}$ & $\mathbf{2 0 0 2}$ & $\mathbf{2 0 0 3}$ & $\mathbf{2 0 0 4}$ & $\mathbf{2 0 0 5}$ & $\mathbf{2 0 0 6}$ & $\mathbf{2 0 0 7}$ & $\mathbf{2 0 0 8}$ & $\mathbf{2 0 0 9}$ & $\mathbf{2 0 1 0}$ & $\mathbf{2 0 1 1}$ & $\mathbf{2 0 1 2}$ & $\mathbf{2 0 1 3}$ \\
\hline EU-28 & 61.8 & 60.9 & 60.3 & 61.9 & 62.2 & 62.7 & 61.5 & 58.9 & 62.2 & 74.5 & 78.2 & 80.8 & 83.5 & 85.4 \\
EA-18 & 69.2 & 68.2 & 68.0 & 69.2 & 69.6 & 70.3 & 68.6 & 66.4 & 70.2 & 80.0 & 83.7 & 85.8 & 89.0 & 90.9 \\
\hline \multicolumn{1}{c}{ Source: Eurostat } & \multicolumn{10}{c}{}
\end{tabular}

The trends on the public debt of the EA countries (Figure 5) indicates that despite the efforts in reducing fiscal deficit, the indebtedness increased significantly for: Cyprus (from 53.5\% of GDP in 2009 up to $102.2 \%$ of GDP in 2013), Greece (from 126.8\% of GDP in 2009 up to $174.9 \%$ of GDP in 2013), Portugal (from $83.6 \%$ of GDP in 2009 up to $128.0 \%$ of GDP in 2013), Spain (from 52.7\% of GDP in 2009 up to $92.1 \%$ of GDP in 2013) and also Slovenia (from $34.5 \%$ of GDP in 2009 up to $70.4 \%$ of GDP in 2013).
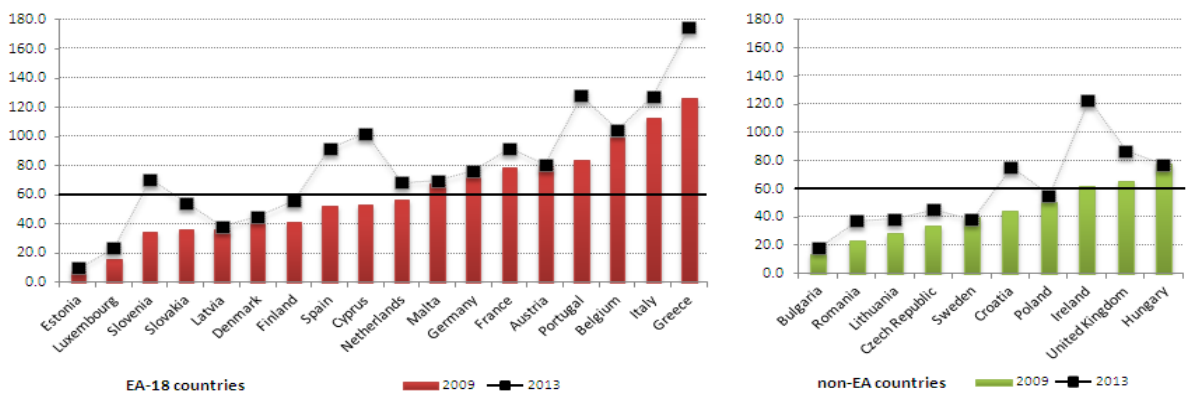

Figure 5 Trends and improvements in public debt for EA-18 and non-EA member states, 2013/2009 (\% of GDP)

Source: Own processing, based on the data available on Eurostat 
Although the level of indebtedness have not increased as much as the countries mentioned before, in case of Italy, given the poor management of debt to GDP even before the financial crisis begin, in 2013 the sovereign debt was $127.9 \%$ of GDP. For Italy, this situation is in opposition to that of the fiscal balance, with some exceptions, was kept within the convergence criterion limit (Bucur \& Dragomirescu, 2013).

In the context of considerable variation across countries, the other EA members also recorded increases in public debt. Yet, in contrast we find a rigorous management of public debt in: Estonia, Denmark, Luxembourg and Finland, where the emergence of financial turmoil has not affected the debt level so that its level remained below the imposed convergence criterion of $60 \%$ of GDP.

Across the EU states that are not EA members, we can find the same situation of considerable variation in terms of government debt to GDP. While Ireland faces a high level of indebtedness (from $62.2 \%$ of GDP in 2009 up to $123.3 \%$ of GDP in 2013), countries such as Croatia, United Kingdom and Hungary has also debts ratios above the $60 \%$ of GDP in 2013, there are countries that demonstrate a more rigorous control of public debt: Bulgaria, Romania, Sweden Lithuania, Czech Republic and Poland.

\section{The impact of austerity fiscal measures in some EU states}

In the actual context, the main priority for both national and EU levels, among others, the continuation of differentiated fiscal consolidation, given the specificities of each EU economy, favoring economic growth.

If we analyze the adoption, application and enforcement of the fiscal policy rule expressed by the evolution of Fiscal Rule Index (FRI), which summarizes information regarding on legal basis of the rule, space for a review, mechanisms for monitoring the compliance and implementation of the rule, and also existence of pre-defined enforcement mechanisms and media visibility rule, we can observe significant variations of the indicator over the last years in the EU and especially in EA states, that should not manifest in a single currency zone (Bucur \& Dragomirescu, 2013).

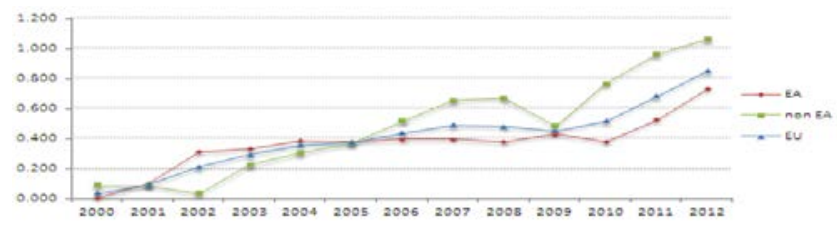

Figure 6 Average of Fiscal Rule Index in EU, 2000-2012

Source: Own processing, based on the data available on European Commission

In the recent years, there is a slight increase growth of the average of FRI in the EU, the Euro area and also in the non-EA members (Figure 6), situation that highlights the importance of fiscal rules especially in the fiscal management of the EA states.

However, for some EA states such as Greece, Spain and Italy, the austerity therapy has not brought the quite expected improvement in terms of macroeconomic aggregate like: public deficit and debt and especially unemployment. It can be observed that, despite their efforts in fiscal consolidation, these three countries faced with a huge challenge: the unemployment, whose level increased enormously since 2009, reaching very high levels of $27.5 \%$ in Greece, $26.1 \%$ in Spain and a slightly lower one of $12.2 \%$ in Italy (Figure 7).

Therefore, the fiscal measures not only amplified the economic imbalancies but have also brought the Euro area into a deep social crisis and pose a threat to the welfare state (Heise \& Lierse, 2011). Other authors share the same opinion, considering that 
fiscal consolidation process was not quite effective as debt stabilization failed in some cases and also that austerity measures were not socially balanced as asymmetric welfare losses and extreme downward real wage adjustments confirmed (Busch et al, 2013; Semmler \& Semmler, 2013).

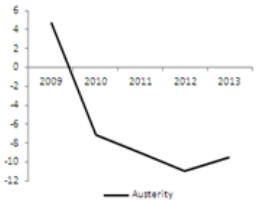

- vungerit

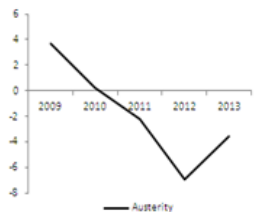

一 Aunatit

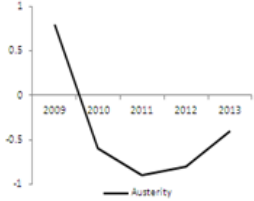

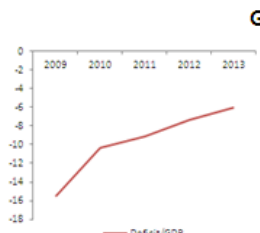

Greece

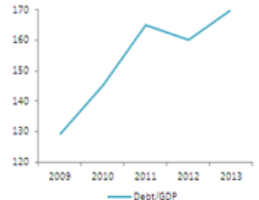

Spain
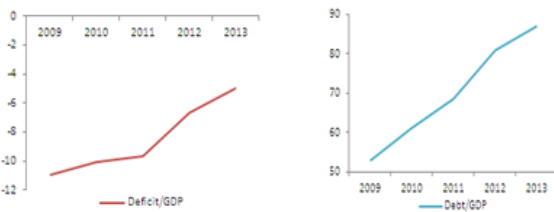

Italy
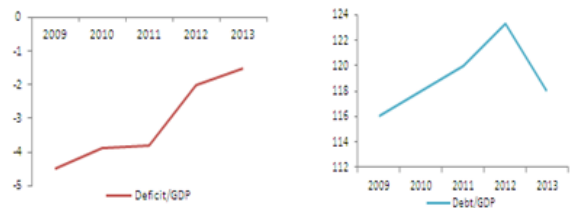
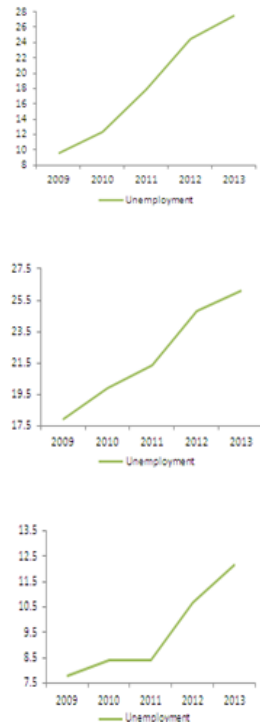

Figure 7 Macroeconomic aggregates for Greece, Spain and Italy, 2010-2013 (\%) Source: Own processing, based on the data available on Eurostat

In accordance with European Commission, the fiscal austerity will not continue once the member states will put their fiscal house in order, and they ensure that their expenditure is financed, which otherwise is a normal practice to ensure sustainability of public finances (European Commission, 2013).

\section{The fiscal consolidation effort and the role of budgetary institutions in supporting it}

On the path towards fiscal union in EU, a first step in fulfillment of the commitments of the Treaty on Stability Coordination and Governance (TSCG) (signed in march 2012) in the EMU, the legislative package applied only to the EA member states, the so called Two Pack, being based on the surveillance mechanisms reformed by the Six Pack to improve fiscal policy-making in the EA, entered into force on the $30^{\text {th }}$ of 2013. The TSCG introduce into national legislation key elements of the Strength and Growing Pact (SGP): (i) the country specific Medium-Term Budgetary Objective (MTO) for strengthening the public finances when the context is favorable in order to create enough fiscal space for periods of macroeconomic imbalances and (ii) the adjustment path towards MTO (European Commission, 2013).

Defined as "cyclically-adjusted general government budget position, net of one-off and other temporary measures", the MTOs should be set in order to:

"(i) Provide a safety margin with respect to the 3\% of GDP deficit limit. For each Member State, this safety margin is estimated in the form of the minimum benchmark, which takes into account past output volatility and budgetary sensitivity to output fluctuations. 
(ii) Ensure sustainability or rapid progress towards sustainability. This is assessed against the need to ensure the convergence of debt ratios towards prudent levels, with due consideration to the economic and budgetary impact of ageing populations.

(iii) In compliance with (i) and (ii), allow room for budgetary manoeuvre, in particular taking into account the needs for public investment." (Council Regulation 1466/97).

According to the recent available data on AMECO and European Commission, the adjustment in consolidation effort in 2013 is:

- mostly expenditure-based in: Greece, Ireland, Lithuania, Poland and Slovenia;

- a mix o revenue-based and expenditure-based in: Belgium, Italy, Romania and Spain;

- mostly revenue-based in: Czech Republic, Finland, France, Luxembourg, Netherlands and Portugal;

- a balanced composition, whereas structural balance evolution shows an expenditure-based consolidation in Slovakia;

- mostly expenditure-base, whereas the structural balance evolution indicates the opposite in United Kingdom.

The countries which have not yet reached their specific MTO will have to continue improving their budgetary positions in order to correct their excessive deficits and to fulfill their target. It is also necessary that this fiscal consolidation to continue differentiated according to the available fiscal space and also with an increased attention to the growth effects of the implemented measures.

The European Commission suggests that the consolidation efforts must be mainly expenditure-based because the fiscal burden is at high level in most countries, though the challenges stemming from population ageing creates a higher pressure on public expenditures (European Commission, 2013).

In fiscal consolidation process is also extremely essential the ensuring of effective budgetary institutions.

Theoretical and empirical analysis shows that a strong institutional framework can improve fiscal performance (eg. Von Hagen, 1992; von Hagen and Harden, 1996; Alesina et al., 1999; de Haan et al., 1999; Gleich, 2003; Hallerberg et al, 2009) by highlighting the need for sustainable policies, exposing the full cost of public interventions, emphasizing collective responsibility over sectoral interests, and raising the cost of deviating from stated fiscal objectives (Olden et al., 2012).

Focus on ten Southern European countries Olden et al. (2012) identify a subset of ten budgetary institutions that have the ability to improve fiscal consolidation at the essential stages of fiscal policy making process:

Tabel 4 Budgetary institutions for supporting fiscal consolidation

\begin{tabular}{cl}
\hline Stages of fiscal policy making process & \multicolumn{1}{c}{ Budgetary institutions } \\
\hline I. UNDERSTANDING THE SCALE AND & 1. Fiscal Reporting \\
SCOPE OF THE FISCAL CHALLENGE & 2. Macroeconomic and Fiscal Forecasting \\
& 3. Fiscal Risk Disclosure and Management \\
& 4. Medium-term Fiscal Objectives \\
II. DEVELOPING A CREDIBLE FISCAL & 5. Medium-term Budget Frameworks \\
CONSOLIDATION STRATEGY & 6. Independent Fiscal Agencies \\
& 7. Performance Orientation \\
III. IMPLEMENTING THE CONSOLIDATION & 8. Top-down Budgeting \\
STRATEGY & 9. Parliamentary Budget Approval \\
& 10. Budget Execution \\
\hline
\end{tabular}

Source: Apud. Olden, B et al. (2012), Fiscal Consolidation in Southern European

Countries: the Role of Budget Institutions, IMF Working Paper WP/12/113, p. 9 


\section{Conclusions}

In the context of the turmoil in financial market caused by the global crisis, many studies focus their attention on the issue of the fiscal consolidation, especially over the last years.

Based on theoretical and empirical research in the field and on the available data on Eurostat and European Commission, this paper aims to capture, in the context of financial significant imbalances and thus of the financial stress in the EU countries and especially in the Euro area, the main developments in the fiscal consolidation process given the fiscal effort of each country.

The gradual accumulation of substantial budget deficits which also led to an increased sovereign debt in many EU Member States indicates an obvious macroeconomic imbalance which requires increased responsibility regarding fiscal developments. The continuously increasing of public debt in some EU member states and the heterogeneity across countries reflects the cumulative effect of high primary deficits, of negative or weak economic growth and also of high interest expenditures.

In this context, the main priority for EU members must be the continuation of differentiated fiscal consolidation, given the specificities of each economy, favoring growth. Thus, medium-term fiscal policy needs to focus on consolidating public finances along with restoring long-term sustainability.

We consider that the ambitious objectives regarding structural balancing of public finance and the reduction of public debt ratio will require a longer period of time, especially for those countries heavily indebted and also effective budgetary institutions essential in fiscal consolidation process.

\section{References}

Alesina, A., Hausmann, R., Hommes, R., Stein, E. (1999), Budget Institutions and Fiscal Performance in Latin America, Inter-American Development Bank Office of the Chief Economist, Working Paper Series, 394, available at http://www.iadb.org/res/publications/pubfiles/pubWP-394.pdf.

Bargain, O., Dolls, M., Fuest, C., Neumann, D., Peichl, A., Pestel, N., Siegloch, S. (2012), Fiscal Union in Europe? Redistributive and Stabilising Effects of an EU Tax-Benefit System, IZA Discussion Paper, 6585, available at http://ftp.iza.org/dp6585.pdf.

Bordo, M., Markiewicz, A., Jonung, L. (2011), A Fiscal Union for the Euro: Some Lessons From History, NBER Working Paper, 17380, available at http://www.nber.org/papers/w17380.pdf.

Bucur, I. A., (2013), Dimensiuni ale extinderii şi adâncirii integrării economice europene, Bacău, Editura Alma Mater.

Bucur, I. A., Dragomirescu, S. E. (2013), An Analysis of the Fiscal Convergence Criteria in the European Union in Terms of the Sustainability, Studies and Scientific Researches. Economics Edition, 18, 137-149, available at http://sceco.ub.ro/DATABASE/repec/pdf/2013/20131817.pdf.

Busch, K., Hermann, C., Hinrichs, K., Schulten, T. (2013), Euro Crisis, Austerity Policy and the European Social Model, Friedrich-Ebert-Stiftung, Internationale Politikanalyse, Berlin, available at http://library.fes.de/pdffiles/id/ipa/09656.pdf.

Council of European Union (1997), Council Regulation (EC) No 1466/97 on the strengthening of the surveillance of budgetary positions and the surveillance and coordination of economic policies, available at http://eurlex.europa.eu/legal-content/EN/TXT/PDF/?uri=CELEX:31997R1466\&from=EN.

European Commission, EUROSTAT, available at http://epp.eurostat.ec.europa.eu. 
European Commission (2013), Report on Public finances in EMU, European Economy 4/2013, Brussels, available at http://ec.europa.eu/economy_finance/ publications/european_economy/2013/pdf/ee-2013-4.pdf.

Fuest, C., Peichl, A. (2012), European Fiscal Union: What Is It? Does It Work? And Are There Really 'No Alternatives'?, IZA Discussion Paper, 39, available at http://ftp.iza.org/pp39.pdf.

Gleich, H. (2003), Budget Institutions and Fiscal Performance in Central and Eastern European Countries, European Central Bank Working Paper, 215, available at https://www.ecb.europa.eu/pub/pdf/scpwps/ecbwp215.pdf.

Grimaldi, M. B. (2010), Detecting and Interpreting Financial Stress, European Central Bank Working Paper Series, 1214, available at http://www.ecb.europa.eu/pub/pdf/scpwps/ecbwp1214.pdf.

Grimaldi, M. B. (2011), Up for Count? Central Bank Words and Financial Stress, Sveriges Riksbank Working Paper Series, 252, available at http://www.riksbank.se/Upload/Dokument_riksbank/Kat_publicerat/WorkingP apers/2011/wp252.pdf.

de Haan, J., Moessen, W., Volkerink, B. (1999), Budgetary Procedures - Aspects and Changes: New Evidence for Some European Countries, in Poterba, J., von Hagen, J. (eds.) (1999), Fiscal Institutions and Fiscal Performance, Chicago University Press.

von Hagen, J. (1992), Budgeting Procedures and Fiscal Performance in the European Communities, European Commission Economic Papers, 96, available at http://aei.pitt.edu/37058/1/A3038.pdf.

von Hagen, J., Harden, I. (1996), Budget Processes and Commitment to Fiscal Discipline, IMF Working Paper 96/78, available at http://ssrn.com/abstract $=882975$.

Hallerberg, M., Strauch, R., von Hagen, J. (2009), Fiscal Governance: Evidence from Europe, Cambridge University Press.

Heise, A., Lierse, H. (2011), Haushaltskonsolidierung und das Europäische Sozialmodell, Friedrich-Ebert-Stiftung, Internationale Politikanalyse, Berlin, available at http://library.fes.de/pdf-files/id/ipa/07890.pdf.

Kim, J., Vammalle, C. (2012), Institutional and Financial Relations across Levels of Government, OECD Fiscal federalism Studies - KIPF, OECD Publishing.

Kliesen, K., Owyang, M., Vermann, K. (2012), Disentangling Diverse Measures: A Survey of Financial Stress Indexes, Federal Reserve Bank of St. Louis Review, 94(5), 369-397, available at http://research.stlouisfed.org/publications/review /12/09/369-398Kliesen.pdf.

Mittnik, W., Semmler, S. (2012), Estimating a Banking-Macro Model for Europe Using a Multi-Regime VAR, SSRN Working paper, available at http://ecomod.net/system/files/BankingFebr13Macromodel2012JEDC.pdf.

Olden, B., Last, D., Ylaoutinen, S., Sateriale, C. (2012), Fiscal Consolidation in Southeastern European Countries: The Role of Budget Institutions, IMF Working Paper WP/12/113, available at https://www.imf.org/external/pubs/ft/ wp/2012/wp12113.pdf.

Sapir, A. (2011), European Integration at the Crossroads: A Review Essay on the $50^{\text {th }}$ Anniversary of Bela Balassa's Theory of Economic Integration, Journal of Economic Literature, 49(4), 1200-1229.

Semmler, W., Greiner, A., Zhang, W. (2005), Monetary and Fiscal Policies in the Euro-Area: Macro Modelling, Learning and Empirics, Emerald Group Publishing Limited.

Semmler, W., Semmler, A. (2013), The Macroeconomics of Fiscal Consolidation in the European Union, SSRN Working paper, available at http://dx.doi.org/10.2139/ssrn.2320198. 
Stein, J. L. (2011), The Diversity of Debt Crisis in Europe, Cato Journal, 31(2), 199215, available at http://object.cato.org/sites/cato.org/files/serials/files/catojournal/2011/5/cj31n2-2.pdf.

Viren, M. (2012), Problems of Fiscal Consolidation and Policy Coordination, Discussion Paper, 82, Aboa Centre for Economics, University of Turku, available at http://www.ace-economics.fi/kuvat/dp82.pdf. 